\title{
Pyruvate and Acetate Metabolism in the Photosynthetic Bacterium Rhodobacter capsulatus
}

\author{
By JOHN C. WILLISON \\ Laboratoire de Biochimie Microbienne (CNRS UA 1130)/DRF/LBIO, Département de \\ Recherche Fondamentale, Centre d'Etudes Nucléaires de Grenoble, 85 X, 38041 Grenoble Cedex, \\ France
}

(Received 11 April 1988; revised 26 May 1988)

\begin{abstract}
Enzymes involved in pyruvate metabolism were assayed in crude extracts of Rhodobacter capsulatus cells grown photosynthetically with different carbon sources. Pyruvate dehydrogenase, pyruvate carboxylase, pyruvate kinase and phosphoenolpyruvate carboxykinase (ATP) were all present in extracts of cells grown on DL-lactate, whereas phosphoenolpyruvate carboxylase, phosphoenolpyruvate synthase and pyruvate, orthophosphate dikinase were undetectable in extracts of cells grown on either DL-lactate, DL-malate or acetate. Malate-grown cells and acetate-grown cells contained lower levels of pyruvate carboxylase and higher levels of pyruvate kinase than did lactate-grown cells, and malate-grown cells also contained lower levels of phosphoenolpyruvate carboxykinase. Pyruvate dehydrogenase activity was undetectable in extracts of acetate-grown cells. Two mutant strains, which were unable to grow on pyruvate, lactate or any other compound metabolized via pyruvate, were found to be deficient in pyruvate carboxylase activity, indicating that this anaplerotic enzyme is essential for growth on pyruvate or related compounds as sole added carbon source. This requirement for pyruvate carboxylase can be bypassed to some extent, however, since the mutants grew on acetate, albeit more slowly than the wild-type and after a long lag period. The key enzymes of the glyoxylate cycle, isocitrate lyase and malate synthase, were present at high levels in extracts of acetate-grown cells, both of the mutants and of several wild-type strains tested, whereas isocitrate lyase activity was undetectable in three different strains of Rhodobacter sphaeroides. This is consistent with previous suggestions that acetate is assimilated via the glyoxylate cycle in $R$. capsulatus but not in $R$. sphaeroides.
\end{abstract}

\section{INTRODUCTION}

The photosynthetic bacterium Rhodobacter capsulatus (formerly Rhodopseudomonas capsulata; Imhoff et al., 1984) is characterized by a vigorous photoproduction of $\mathrm{H}_{2}$ when grown and incubated in the light, under conditions of nitrogen limitation (for review, see Vignais et al., 1985) $\mathrm{H}_{2}$ production is catalysed by the nitrogenase enzyme (EC 1.18.6.1), which under anaerobic conditions, and in the absence of $\mathrm{N}_{2}$ or other substrate, catalyses the two-electron reduction of $\mathrm{H}^{+}$to $\mathrm{H}_{2}$. Reduction of $\mathrm{H}^{+}$or other substrate requires ATP, which is provided at optimal rates by photosynthesis, although $\mathrm{N}_{2}$ fixation can also occur under dark, anaerobic or semi-aerobic conditions. A low-potential reductant is also required, and the reducing power necessary is provided by the oxidation of organic substrates.

Non-growing ('resting') cell suspensions are theoretically capable of oxidizing organic substrates quantitatively to $\mathrm{H}_{2}$ and $\mathrm{CO}_{2}$ (cf. Macler et al., 1979). However, in practice, the yield of $\mathrm{H}_{2}$ is less than the theoretical maximum. The highest values (approx. $80 \%$ ) are observed with

Abbreviations: CS, citrate synthase; DTNB, 5,5'-dithio-bis(2-nitrobenzoic acid); ICL, isocitrate lyase; MS, malate synthase; PC, pyruvate carboxylase; PCK, phosphoenolpyruvate carboxykinase; PDH, pyruvate dehydrogenase; PK, pyruvate kinase; PPS, phosphoenolpyruvate synthase. 
organic acids such as lactate and malate, whereas much lower values are observed with sugars (Hillmer \& Gest, 1977b). The basis for this low conversion efficiency is not known, although the residual $[\mathrm{H}]$ is presumably excreted into the medium in the form of reduced carbon compounds, possibly the end-products of fermentation-type reactions. Mutants of Rhodobacter capsulatus have been isolated which show an increased efficiency of $\mathrm{H}_{2}$ production from certain organic substrates (Willison et al., 1984). These mutants excrete lower quantities of reduced carbon into the culture medium than the wild-type, and also have increased levels of D-malic enzyme. However, the precise nature of the lesion in these mutants has not been identified.

In order to understand the factors determining the efficiency of conversion of organic substrates to $\mathrm{H}_{2}$, a detailed understanding of the carbon metabolism of Rhodobacter capsulatus is required. The carbon metabolism of many photosynthetic bacteria, including $R$. capsulatus, has been extensively studied (for reviews see Fuller, 1978; Kondratieva, 1979). However, a systematic study of a Rhodobacter species has not been made. Hence, detailed schemes of carbon metabolism could be drawn for Rhodopseudomonas palustris and Rhodospirillum rubrum, but not for Rhodobacter capsulatus or Rhodobacter sphaeroides (Kondratieva, 1979). In R. capsulatus, glucose is metabolized via the Entner-Doudoroff pathway (Eidels \& Preiss, 1970b), fructose via the Embden-Meyerhoff pathway (Conrad \& Schlegel, 1974), and $\mathrm{CO}_{2}$-fixation during autotrophic growth occurs via the Calvin cycle (Stoppani et al., 1955). However, the enzymes involved in pyruvate metabolism have not been clearly identified, and only pyruvate kinase has been studied in detail (Klemme, 1974). Uncertainty also exists concerning the metabolism of acetate. Kornberg \& Lascelles (1960) showed that $R$. capsulatus contains all the enzymes of the glyoxylate cycle, whereas in more recent work, it has been claimed that $R$. capsulatus, like the closely related $R$. sphaeroides, lacks isocitrate lyase (Albers \& Gottschalk, 1976; Kondratieva, 1979).

The present article reports the activity of some of the enzymes involved in pyruvate metabolism in Rhodobacter capsulatus, identifies the enzymic deficiency in two mutant strains unable to grow on pyruvate or related compounds as sole carbon source, and clarifies the role of the glyoxylate cycle in the metabolism of acetate by this organism.

\section{METHODS}

Bacterial strains. These are listed in Table 1. The wild-type Rhodobacter capsulatus strains JH1, LB1 and St Louis were obtained from Dr J. D. Wall, University of Missouri, Columbia, Missouri, USA, and the strains of Rhodobacter sphaeroides were obtained from Dr F. R. Tabita, University of Texas, Austin, Texas, USA. Mutants of $R$. capsulatus were derived from the laboratory strain of $B 10$, which differs from the original isolate in being unable to produce gene transfer agent (Willison et at., 1985).

Growth medium and culture conditions. $R$. capsulatus strains were grown in RCV medium (Weaver et al., 1975; Hillmer \& Gest, 1977a) containing $30 \mathrm{~mm}$-DL-malate as carbon source and $7.5 \mathrm{~mm}-\left(\mathrm{NH}_{4}\right)_{2} \mathrm{SO}_{4}$ as nitrogen source.

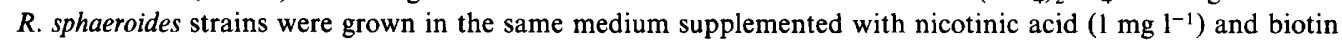
$\left(15 \mu \mathrm{g} \mathrm{l}^{-1}\right)$. When alternative carbon sources were used, RCV medium was prepared without added malate, and the carbon source was added as a filter-sterilized solution after autoclaving. DL-Lactate was used at a concentration of $30 \mathrm{mM}$, and acetate was used at a concentration of $24.4 \mathrm{~mm}$ in medium supplemented with $10 \mathrm{~mm}$ $\mathrm{NaHCO}_{3}$. Cultures were grown in stoppered tubes filled to capacity with growth medium and incubated at $30^{\circ} \mathrm{C}$ under saturating illumination (about $3000 \mathrm{~lx}$ ).

Isolation of mutants. Strain RC85 was isolated in an experiment designed to isolate glutamate auxotrophs. After mutagenesis of strain B10 with $N$-methyl- $N^{\prime}$-nitro- $N$-nitrosoguanidine, and penicillin selection in RCV medium (see Willison et al., 1985), survivors were plated on RCV agar medium containing 7 mM-glutamate as sole nitrogen source, and colonies were then replica-plated onto RCV agar medium without glutamate, containing $7.5 \mathrm{mM}$ $\left(\mathrm{NH}_{4}\right)_{2} \mathrm{SO}_{4}$ as nitrogen source. Of 1000 colonies tested, one failed to grow in the absence of glutamate. This mutant grew slowly on lactate/glutamate medium, reverting frequently to the wild-type, but it was subsequently found to grow well on RCV medium containing DL-malate as carbon source, in either the presence or the absence of glutamate. Its growth on lactate/glutamate medium was therefore due to its use of glutamate as both carbon and nitrogen source. The isolation of strain $\mathrm{RC} 87$ has been described previously (Willison et al., 1987). This strain lacks the endogenous plasmid which is present in strain B10, but also contains a chromosomal insertion of DNA derived from the plasmid pTH10, which is probably responsible for the mutation (Willison et al., 1987).

Measurement of bacterial growth. The growth of cultures was followed by diluting a sample of the culture in RCV medium without carbon or nitrogen source and measuring the $\mathrm{OD}_{660}$. Growth rates were determined from growth 
Table 1. Bacterial strains

Strain

$R$. sphaeroides WS22 Lys $^{+}$

$2.4 .1 \mathrm{Ga}$

HR

R. capsulatus

JH1

LB1

St Louis

B10

RC85

$\mathrm{RC} 87$

$\mathrm{RC} 112$

$\mathrm{RC} 113$

RC225
Phenotype/genotype*

Prototroph

Prototroph

$\operatorname{Str}^{\mathrm{r}}$

Wild-type
Wild-type
Wild-type
Wild-type
${\text { Pyu- } / \text { Pyc }^{-}(p y c-l)}_{\text {Pyu }^{-} / \mathrm{Pyc}^{-}(p y c-2) \text { rif- }^{-} \mathrm{Km}^{\mathrm{r}} \mathrm{Tc}^{\mathrm{r}}(\mathrm{pTH} 10)}$
$\mathrm{Pyu}^{+} / \mathrm{Pyc}^{+}$rif-4 $\mathrm{Km}^{\mathrm{T}} \mathrm{Tc}^{\mathrm{r}}(\mathrm{pTH} 10)$
Pyu $^{ \pm} / \mathrm{Pyc}^{-}$rif-4 $\mathrm{Km}^{\mathrm{r}} \mathrm{Tc}^{\mathrm{r}}(\mathrm{pTH} 10)$
$\mathrm{Pyu}^{+} / \mathrm{Pyc}^{+}$

Comments and/or source or reference

Spontaneous, prototrophic revertant of WS22

(Sistrom, 1977)

Spontaneous, green mutant of 2.4.1

(Gibson \& Tabita, 1977)

Spontaneous derivative of ATCC 17023

(Weaver \& Tabita, 1983)

Weaver et al. (1975)

J. D. Wall

Weaver et al. (1975)

Marrs (1974); Willison et al. (1985)

This study

Willison et al. (1987)

Spontaneous, fast-growing revertant of RC87

Spontaneous, slow-growing revertant of RC87 Spontaneous revertant of RC85

* $\mathrm{Km}^{\mathrm{r}}$, kanamycin resistance; pyc/Pyc, pyruvate carboxylase activity; Pyu, utilization of pyruvate and related substrates; rif, rifampicin; $\mathrm{Str}^{r}$, streptomycin resistance; $\mathrm{Tc}^{\mathrm{r}}$, tetracycline resistance.

curves obtained by measuring the $\mathrm{OD}_{660}$ of cultures directly in a Bausch and Lomb Spectronic spectrophotometer, as described previously (Willison et al., 1984).

Preparation of cell-free extracts. Cells were routinely harvested from growing cultures, at an $\mathrm{OD}_{660}$ of about $2 \cdot 0$ when DL-malate or DL-lactate was the carbon source, and 1.0 when acetate was the carbon source. Samples (20$50 \mathrm{ml}$ ) of culture were centrifuged at $10000 \mathrm{~g}$ for $10 \mathrm{~min}$, at $4{ }^{\circ} \mathrm{C}$; the cells were resuspended in $10-20 \mathrm{ml} 20 \mathrm{mM}$ Tris/ $/ \mathrm{HCl}, \mathrm{pH} 7.8$, centrifuged again as above, and resuspended in $1-2 \mathrm{ml} 20 \mathrm{~mm}$-Tris $/ \mathrm{HCl}, \mathrm{pH} 7.8$. The cells were broken by sonication three times for $45 \mathrm{seach}$ with $1 \mathrm{~min}$ cooling intervals in ice, using a Heat Systems Ultrasonics model W-10 sonicator. The suspension was then centrifuged at $20000 \mathrm{~g}$ for $2 \mathrm{~min}$, in an Eppendorf Microcentrifuge, to remove cell debris, then at $100000 \mathrm{~g}$ for $1 \mathrm{~min}$ in a Beckman Airfuge to remove membrane fragments. The extracts thus obtained (supernatant fraction) were stored on ice until use, except fractions to be assayed for pyruvate kinase activity, which were stored at room temperature.

Measurement of protein concentration. The protein content of cell-free extracts was determined by the Lowry method, using bovine serum albumin (Sigma, fraction V), as standard.

Enzyme assays. All enzymes were assayed spectrophotometrically by previously published methods, which were either used as described or slightly modified. The reactions, which were carried out at $30^{\circ} \mathrm{C}$ in a final volume of $1 \mathrm{ml}$, were generally started by the addition of extract (between $5 \mu \mathrm{l}$ and $100 \mu \mathrm{l}$, at a concentration of $1-5 \mathrm{mg}$ protein $\mathrm{ml}^{-1}$ ) after a preincubation of $2-5 \mathrm{~min}$ at $30^{\circ} \mathrm{C}$, during which time the absorbance was monitored. Reaction rates were calculated from the change in $A_{340}$ due to the oxidation of NADH or the reduction of $\mathrm{NAD}^{+}$ ( $\varepsilon=6.22 \mathrm{~mm}^{-1} \mathrm{~cm}^{-1}$ ) or the change in $A_{412}$ due to the reduction of 5,5'-dithio-bis(2-nitrobenzoic acid) (DTNB) $\left(\varepsilon=13.6 \mathrm{~mm}^{-1} \mathrm{~cm}^{-1}\right)$. Each assay was done with at least two different concentrations of extract to check for proportionality of activity to protein concentration.

Pyruvate dehydrogenase (EC 1.2.4.1) was assayed as described by Guest \& Creaghan (1973), except that 3acetyl-NAD ${ }^{+}$was replaced with $\mathrm{NAD}^{+}$, and the concentration of coenzyme A was increased twofold. The composition of the reaction mixture was as follows: Tris $/ \mathrm{HCl}, \mathrm{pH} 8.5,120 \mathrm{mM}$; coenzyme $\mathrm{A}(\mathrm{CoA}), 0.16 \mathrm{mM}$; Lcysteine. $\mathrm{HCl}, 3 \mathrm{mM}$; thiamin pyrophosphate, $0.2 \mathrm{~mm} ; \mathrm{NAD}^{+}, 0.8 \mathrm{~mm}$; sodium pyruvate, $7.5 \mathrm{mM}$. The increase in $A_{340}$ was generally linear with time for at least $2 \mathrm{~min}$ after the addition of extract. The rate of $\mathrm{NAD}^{+}$reduction was corrected for the basal rate in the absence of added pyruvate, although this was usually negligible.

Pyruvate carboxylase (EC 6.4.1.1) activity was assayed by coupling the production of oxaloacetate to the reduction of DTNB, using citrate synthase, as described by Payne \& Morris (1969). The reaction mixture comprised: Tris/ $\mathrm{HCl}, \mathrm{pH} 7.8,100 \mathrm{~mm} ; \mathrm{MgCl}_{2}, 10 \mathrm{mM}$; sodium pyruvate, $10 \mathrm{~mm} ; \mathrm{NaHCO}_{3}, 50 \mathrm{mM} ; \mathrm{ATP}, 5 \mathrm{~mm}$; acetyl-CoA, $0.2 \mathrm{mM}$; DTNB, $0.2 \mathrm{mM}$; citrate synthase, $5 \mathrm{U}$. The reaction rate was calculated from the difference in the rate of DTNB reduction in the presence or absence of ATP, and was linear for about $2 \mathrm{~min}$ after the addition of extract. For determination of the $\mathrm{pH}$ optimum of pyruvate carboxylase activity, the $\mathrm{Tris} / \mathrm{HCl}$ buffer was adjusted to $\mathrm{pH}$ values between 7.2 and 9.0, and was replaced by MOPS/NaOH for $\mathrm{pH}$ values between 6.0 and 7.2 . At $\mathrm{pH} 7.2$, the specific activity in the presence of MOPS was not significantly different from that in the presence of Tris. 
Phosphoenolpyruvate carboxykinase (ATP) (EC 4.1.1.49) activity was assayed as described by Schobert \& Bowien (1984), except that ADP was substituted for GDP. The reaction mixture contained: $\mathrm{MOPS} / \mathrm{NaOH}$, pH 6.6, $100 \mathrm{~mm} ; \mathrm{NaHCO}_{3}, 50 \mathrm{~mm}$; phosphoenolpyruvate, $5 \mathrm{~mm}$; ADP, $5 \mathrm{mM}$; NADH, $0.25 \mathrm{mM} ; \mathrm{MnCl}_{2}, 2 \mathrm{mM}$; $\mathrm{MgCl}_{2}, 2 \mathrm{mM}$; malate dehydrogenase, $5 \mathrm{U}$. The decrease in $A_{340}$ was linear for at least $5 \mathrm{~min}$ after the addition of extract. The rate of NADH oxidation was corrected for the basal rate in the absence of added ADP.

Pyruvate kinase (EC 2.7.1.40) was assayed as described by Hess \& Wieker (1974). The reaction mixture consisted of: Tris/ $\mathrm{HCl}, \mathrm{pH} 7.5 ; 100 \mathrm{mM} ; \mathrm{MgSO}_{4}, 30 \mathrm{~mm}$; NADH, $0.25 \mathrm{~mm}$; phosphoenolpyruvate, $5 \mathrm{~mm}$; ADP, $10 \mathrm{mM}$; lactate dehydrogenase, $5 \mathrm{U}$. The decrease in $A_{340}$ was linear for up to $5 \mathrm{~min}$ after the addition of extract. The rate of NADH oxidation was corrected for the basal rate in the absence of ADP.

Phosphoenolpyruvate synthase (EC 2.7.9.2) (forward and reverse reactions), phosphoenolpyruvate carboxylase (EC 4.1.1.31) and pyruvate, orthophosphate dikinase (EC 2.7.9.1) were tested for as described by Schobert \& Bowien (1984). The reaction medium for assaying the phosphoenolpyruvate synthase forward reaction contained: Tris/ $\mathrm{HCl}, \mathrm{pH} 8.8,110 \mathrm{mM}$; ATP, $10 \mathrm{~mm} ; \mathrm{NaHCO}_{3}, 20 \mathrm{~mm} ; \mathrm{NADH}, 0.25 \mathrm{~mm} ; \mathrm{MgCl}_{2}, 10 \mathrm{~mm}$; sodium pyruvate, $1.5 \mathrm{mM}$; malate dehydrogenase, $5 \mathrm{U}$; phosphoenolpyruvate carboxylase, $0.5 \mathrm{U}$. The assay medium was also modified by replacing the NADH and malate dehydrogenase with DTNB $(0.2 \mathrm{mM})$ and citrate synthase (5 U).

Citrate synthase (EC 4.1.3.7) was assayed as described by Eidels \& Preiss (1970a) and isocitrate lyase (EC 4.1.3.1) and malate synthase (EC 4.1.3.2) were assayed as described by Dixon \& Kornberg (1959). In the latter two assays, the reaction was initiated by the addition of substrate rather than extract.

Chemicals. All enzymes, nucleotides and cofactors were purchased from Boehringer Mannheim, as was DTNB. Other reagents were purchased from Sigma or from Prolabo, and were of the highest purity available.

\section{RESULTS}

\section{Growth experiments}

The wild-type strain B10 of Rhodobacter capsulatus is able to use a wide range of carbon sources for growth (see Weaver et al., 1975). The growth characteristics of the mutant strain RC87 have been described previously: L-malate, succinate, glutamate, butyrate, propionate and acetate serve as sole carbon source, but it is unable to grow on pyruvate, lactate, D-malate, glucose or ribose, or autotrophically on $\mathrm{H}_{2}+\mathrm{CO}_{2}$ (Willison et al., 1987). The mutant strain RC85 was also unable to grow on carbon sources metabolized via pyruvate. The growth phenotype of strain RC87 is apparently due to the presence of a chromosomal insertion of Rplasmid DNA (Willison et al., 1987), while strain RC85 probably carries a point mutation in a gene for pyruvate utilization. Strain RC85 reverted to growth on lactate at a frequency of $1.5 \times$ $10^{-5}$, yielding colonies which grew at a similar rate to those of the wild-type. In contrast, strain RC87 yielded two types of revertant: colonies which grew at a similar rate to those of the wildtype (frequency $1 \times 10^{-6}$ ) and colonies which grew much more slowly (frequency $4 \times 10^{-5}$ ).

The growth rates of these strains on various carbon sources are shown in Table 2 . The mutants $\mathrm{RC} 85$ and $\mathrm{RC} 87 \mathrm{grew}$ at similar rates to the wild-type on acetate, and showed a lag period of about $24 \mathrm{~h}$ before growth on acetate began, compared to a lag period of about $12 \mathrm{~h}$ for the wildtype. Strain RC113, a slow-growing revertant of RC87, grew more slowly than the wild-type on lactate, but grew on acetate with a similar lag period to that shown by the wild-type. Although strains RC85 and RC87 were unable to utilize lactate as sole carbon source for growth, they were able to grow on lactate when the medium was supplemented with a limiting concentration of $\mathrm{L}$ malate. With $4.5 \mathrm{mM}$-L-malate alone, strains grew with a doubling time of about $2.0 \mathrm{~h}$, reaching a final $\mathrm{OD}_{660}$ of 1.0 ; in the presence of $20 \mathrm{mM}$-DL-lactate, growth continued for several hours longer, and the final $\mathrm{OD}_{660}$ was $3 \cdot 0$. Although the present work was done exclusively with photosynthetically grown cultures, the pattern of carbon source utilization by strains grown aerobically in the dark (as judged by the growth rate of colonies on agar plates) was identical to that observed in the light.

The presence of different enzymes likely to be involved in pyruvate utilization was tested for in extracts of cells grown photosynthetically on different carbon sources (DL-lactate, DL-malate, DL-lactate plus L-malate, and acetate). Cells were harvested at standard $\mathrm{OD}_{660}$ values $(0 \cdot 8-1 \cdot 0$ for acetate, and 1.5-2.0 for other substrates). These were well below the stationary phase, but did not necessarily correspond to the phase of maximum growth rate shown in Table 2, which was 
Table 2. Growth rates of wild-type, mutant and revertant strains on various carbon sources

$\begin{array}{lcccccc}\text { Strain } & \begin{array}{c}\text { Relevant } \\ \text { phenotype }\end{array} & \text { DL-Lactate } & \text { DL-Malate } & \text { L-Malate } & \begin{array}{c}\text { DL-Lactate } \\ \text { plus } \\ \text { L-malate }\end{array} & \text { Acetate } \\ \text { B10 } & \text { Pyu }^{+} & 2 \cdot 0 \pm 0 \cdot 0(3) & 2 \cdot 3 & 2 \cdot 0 & 2 \cdot 0 & 3 \cdot 1 \\ \text { RC85 } & \text { Pyu }^{-} & >48 & 2 \cdot 4 & 2 \cdot 0 & 2 \cdot 1 & 3 \cdot 4 \\ \text { RC87 } & \text { Pyu }^{-} & >48 & 3 \cdot 1 & 2 \cdot 1 & 2 \cdot 4 & 3 \cdot 2 \\ \text { RC112 } & \text { Pyu }^{+} & 2 \cdot 7 \pm 0 \cdot 1(4) & 3 \cdot 0 & 2 \cdot 1 & 2 \cdot 0 & 3 \cdot 4 \\ \text { RC113 } & \text { Pyu }^{ \pm} & 4 \cdot 2 \pm 0 \cdot 3(4) & 2 \cdot 5 & 2 \cdot 1 & 2 \cdot 2 & \text { ND } \\ \text { RC225 } & \text { Pyu }^{+} & 2 \cdot 0 \pm 0 \cdot 1(3) & 2 \cdot 2 & 2 \cdot 0 & 2 \cdot 0 & \text { ND }\end{array}$

* See Table 1 .

† Strains were grown photosynthetically on the different carbon sources shown (see text) and the doubling time was calculated from the initial, linear portion of the growth curve. Doubling times on DL-lactate are given as the mean \pm standard error, with the number of determinations in parentheses. Other values are the mean of two separate determinations. ND, Not determined.

Table 3. Enzyme activities in extracts of wild-type strain B10 and mutant strain RC85 grown photosynthetically on various carbon sources

Enzymes were assayed as described in Methods. The values shown [nmol $\min ^{-1}(\mathrm{mg} \text { protein })^{-1}$ ] are means \pm standard error of determinations on extracts from separate cultures, with the number of determinations in parentheses. ND, Not determined.

\begin{tabular}{|c|c|c|c|c|c|c|}
\hline \multirow{3}{*}{$\begin{array}{l}\text { Enzyme } \\
\text { ydrogenase (PDH) }\end{array}$} & \multicolumn{3}{|c|}{ Strain B10 } & \multicolumn{3}{|c|}{ Strain RC85 } \\
\hline & DL-Lactate & DL-Malate & Acetate & $\begin{array}{l}\text { DL-Lactate } \\
\text { plus L-malate }\end{array}$ & DL-Malate & Acetate \\
\hline & $46 \cdot 5 \pm 6 \cdot 1$ & $60 \cdot 3 \pm 21 \cdot 3$ & $<1 \cdot 0$ & $63 \cdot 0 \pm 29 \cdot 7$ & $45 \cdot 1 \pm 6 \cdot 1$ & $<1 \cdot 0$ \\
\hline C) & $66 \cdot 3 \pm \frac{27 \cdot 2}{(8)}$ & $10 \cdot 4 \underset{(5)}{ \pm} 11 \cdot 3$ & $20 \cdot 2 \pm \frac{15}{(5)} 15 \cdot 4$ & $<1 \cdot 0$ & $<1.0$ & $<1 \cdot 0$ \\
\hline
\end{tabular}

Pyruvate carboxylase (PC)

$(8) \quad(5) \quad(5)$

Phosphoenolpyruvate carboxykinase $46 \cdot 0 \pm 39 \cdot 1 \quad 27 \cdot 5 \pm 25 \cdot 3 \quad 64 \cdot 5 \pm 36 \cdot 5 \quad 102 \cdot 4 \pm 8 \cdot 4$

(ATP) (PCK)

(5)

(7)

(8)

(4)

$48 \cdot 8 \pm 42 \cdot 8101 \cdot 9 \pm 74.9$

Pyruvate kinase (PK)

$2 \cdot 6 \pm 2 \cdot 7 \quad 8 \cdot 3 \pm 4 \cdot 2 \quad 17 \cdot 3 \pm 0 \cdot 8$

ND

(6) (5)

(4)

(3)

(2)

(5)

generally observed between $\mathrm{OD}_{660}$ values of $0 \cdot 2$ and $1 \cdot 0$. The enzyme activities determined for strains B10 (wild-type) and RC85 are shown in Table 3.

\section{Pyruvate dehydrogenase}

Pyruvate dehydrogenase (PDH) activity was detected in extracts of wild-type B10 cells grown on lactate or malate, and was present in similar amounts in extracts of mutants RC85 or RC87 grown on malate or lactate plus malate (Table 3). In contrast to the Escherichia coli enzyme (Langley \& Guest, 1977), PDH activity in $R$. capsulatus was inhibited (by about $20 \%$ ) by $5 \mathrm{~mm}$ $\mathrm{MgCl}_{2}$, and was about $50 \%$ higher and linear for longer time periods when $\mathrm{NAD}^{+}$rather than 3-acetyl-NAD ${ }^{+}\left(\mathrm{APAD}^{+}\right)$was provided as substrate. The optimal concentration of $\mathrm{CoA}$ was also higher (see Methods).

Extracts of acetate-grown cells, both of the wild-type and of the mutants, contained no detectable PDH activity. Reconstitution experiments with extracts of lactate-grown cells showed that extracts of acetate-grown cells contained no inhibitor of $\mathrm{PDH}$ activity, and that the reduction of as little as $1.0 \mathrm{nmol} \mathrm{NAD}{ }^{+} \min ^{-1}(\mathrm{mg} \text { protein })^{-1}$ could be detected. NADH oxidase activity was undetectable in extracts of acetate-grown cells, and low or negligible $[<5 \mathrm{nmol}$ $\left.\min ^{-1}(\mathrm{mg} \text { protein })^{-1}\right]$ in extracts of lactate-grown or malate-grown cells. 


\section{Pyruvate carboxylase}

Pyruvate carboxylase (PC) activity was high in extracts of lactate-grown cells of B10 (Table 3). Initially, PC was assayed as described by Schobert \& Bowien (1984), by coupling the production of oxaloacetate to the oxidation of NADH with malate dehydrogenase. However, in extracts of the mutants RC85 and RC87, as well as in some extracts of malate-grown and acetate-grown $\mathrm{B} 10$, the rate of NADH oxidation was greater in the absence than in the presence of ATP, by up to $20 \mathrm{nmol} \mathrm{m^{-1 }}$ (mg protein) $)^{-1}$. This suggested the presence of a competing enzyme activity which was inhibited by ATP. However, if the production of oxaloacetate was coupled to the reduction of DTNB in the presence of acetyl-CoA and citrate synthase (Payne \& Morris, 1969), then in extracts of the mutants, the activity in the absence of ATP differed from that in the presence of ATP by no more than 1-2 $\mathrm{nmol} \mathrm{min}^{-1}$ (mg protein) $)^{-1}$. It was therefore concluded that the mutant strains RC85 and RC87 were deficient in PC activity. In extracts of the wild-type, the level of PC activity varied widely (Table 3). It was much lower in extracts of malate-grown or acetate-grown cells than in extracts of lactate-grown cells, and was undetectable in some extracts. The fast-growing revertant strains RC112 and RC225 contained similar levels of PC activity to the wild-type $\left[40-50 \mathrm{nmol} \mathrm{min}{ }^{-1}(\mathrm{mg} \text { protein })^{-1}\right]$ when grown on lactate, whereas the slow-growing revertant strain, $\mathrm{RC113}$, contained no detectable PC activity.

In $R$. sphaeroides, PC has an absolute requirement for acetyl-CoA for activation (Payne \& Morris, 1969). This also appears to be the case for the $R$. capsulatus enzyme, since, in the $\mathrm{NADH}$-linked assay, the activity measured in the absence of acetyl-CoA was similar to that measured in the absence of ATP.

When assays for the phosphoenolpyruvate synthase (PPS) forward reaction (see below) were carried out on extracts of lactate-grown B10 cells, an ATP-dependent activity was observed which was independent of the addition of phosphoenolpyruvate carboxylase, and was therefore probably due to PC (the PPS assay medium contained all the components of the PC assay medium, although the $\mathrm{pH}$ and reagent concentrations were different). Generally, this activity was much lower than in the PC assay. However, when an extract of stationary-phase cells was tested, the activities measured in the PC and PPS assays were about the same. This effect was reproduced in several different experiments, and was subsequently found to be due to a difference between the $\mathrm{pH}$-profiles of PC activity in extracts from growing and stationary-phase cells. The pH-profile of PC activity in extracts of growing cells took the form of a classical, bellshaped curve, with a maximum at $\mathrm{pH} 7 \cdot 8$, whereas in extracts of stationary-phase cells, the $\mathrm{pH}$ profile was much broader, with apparently two optima at around $\mathrm{pH} 7 \cdot 1$ and $\mathrm{pH} 8.5$ (Fig. 1).

\section{Phosphoenolpyruvate carboxykinase}

Phosphoenolpyruvate carboxykinase (PCK) activity was easily detected in extracts of lactategrown cells of B10. Activity specifically required ADP, with no activity being observed with GDP or IDP. Activities varied widely between extracts (Table 3), but on average were higher in extracts of acetate-grown cells than in extracts of lactate-grown cells, and lowest in extracts of malate-grown cells. The mutant strains RC85 and RC87 contained approximately twofold higher levels of PCK activity than the wild-type, with the average activity being lower on DLmalate than on acetate or on lactate plus L-malate.

\section{Pyruvate kinase}

Pyruvate kinase (PK) has been shown to be a cold-labile enzyme in both $R$. sphaeroides (Schedel et al., 1975) and $R$. capsulatus (Klemme, 1974), so assays were done on extracts prepared and stored at room temperature. Extracts could be stored for up to $6 \mathrm{~h}$ at room temperature without loss of activity, whereas activity was lost completely after $1 \mathrm{~h}$ at $0{ }^{\circ} \mathrm{C}$. (In contrast, $\mathrm{PC}$ activity decreased by more than $50 \%$ and $\mathrm{PDH}$ activity was lost completely after $6 \mathrm{~h}$ at room temperature, although the activity of PCK remained constant.)

PK activity was low and sometimes undetectable in extracts of lactate-grown cells of B10, but was several-fold higher in extracts of malate-grown or acetate-grown cells (Table 3 ). In extracts of malate-grown cells of RC85 (and RC87), the activity of PK was about fourfold higher than in 


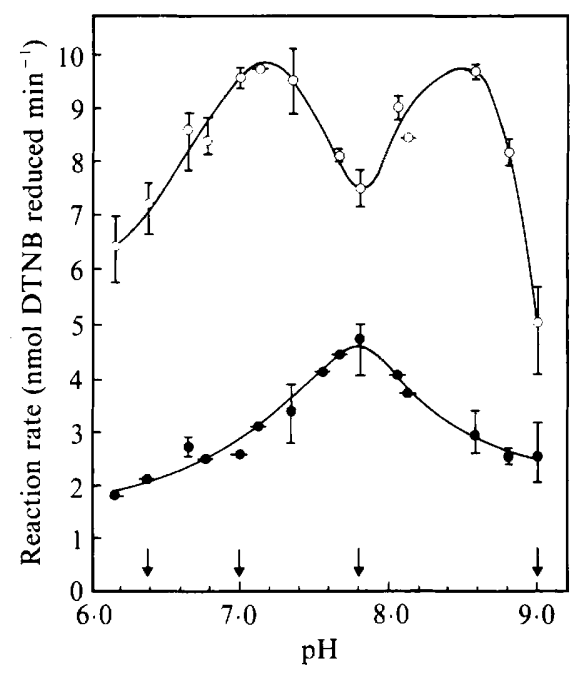

Fig. 1. pH-dependence of PC activity in crude extracts of wild-type (B10) cells. Cells were grown photosynthetically on DL-lactate and harvested in the exponential $(O)$ or stationary $(O)$ phase of growth. Crude extracts were prepared as described in Methods. Reaction mixtures were prepared with or without ATP, using stock solutions of Tris or MOPS adjusted to various $\mathrm{pH}$ values at room temperature; the actual $\mathrm{pH}$ of the reaction mixture was then measured at $30^{\circ} \mathrm{C}$. The reaction was started by the addition of extract $\left(0,89 \mu \mathrm{g}\right.$ protein; $\bigcirc, 105 \mu \mathrm{g}$ protein) and the $A_{412}$ was measured automatically at $20 \mathrm{~s}$ intervals for $2-3 \mathrm{~min}$. The reaction rate was calculated from the slope of the straight line obtained when the curve measured in the absence of ATP was subtracted from the curve measured in the presence of ATP. Duplicate determinations of activity were made at each pH value, and when these values differed by more than $10 \%$, a third determination was made. In all cases, the mean value is shown, and the range of values observed is indicated by the vertical bars (a horizontal bar through a symbol indicates that the values were identical). The proportionality of activity to protein concentration was checked at four different $\mathrm{pH}$ values (indicated by arrows).

malate-grown cells of B10; the activity in extracts of cells grown on other carbon sources was not tested.

\section{Other enzymes}

No evidence was obtained for the presence of phosphoenolpyruvate carboxylase phosphoenolpyruvate synthase (PPS), or pyruvate, orthophosphate dikinase activity in extracts of either growing or stationary-phase cells, after storage at $0^{\circ} \mathrm{C}$ or at room temperature, or by varying the $\mathrm{pH}$ of the reaction medium by \pm 0.5 unit from the value given in the published method. When PPS was assayed by coupling phosphoenolpyruvate formation to the oxidation of NADH, with phosphoenolpyruvate carboxylase and malate dehydrogenase, the rate of NADH oxidation was greater in the absence of ATP than in the presence of ATP, as was observed with the PC assay (see above). When NADH and malate dehydrogenase were replaced with acetyl-CoA, DTNB and citrate synthase, an ATP-dependent activity was observed, which was independent of phosphoenolpyruvate carboxylase, and was therefore probably due to $\mathrm{PC}$, as mentioned above.

Citrate synthase (CS) was present both in the wild-type and in the mutant strains. The activities in extracts of cells grown on DL-malate [235 $\pm 44 \mathrm{nmol} \mathrm{min}^{-1}$ (mg protein) $)^{-1}$ for B10; $246 \pm 37 \mathrm{nmol} \mathrm{min}^{-1}$ (mg protein) ${ }^{-1}$ for RC85] were very similar to those reported by Eidels \& Preiss $(1970 a$ ). These authors made an extensive study of CS in $R$. capsulatus, and found it to be present at higher levels in aerobically grown cells than in anaerobically grown cells for carbon sources other than acetate, and to be present at the highest levels in cells grown aerobically in the dark on acetate $\left[1800 \mathrm{nmol} \mathrm{min}{ }^{-1}(\mathrm{mg} \text { protein })^{-1}\right]$. They did not report the activity in extracts of cells grown photosynthetically on acetate, which we found to be $750 \pm 193 \mathrm{nmol} \mathrm{min}^{-1}(\mathrm{mg}$ protein $)^{-1}$ for $\mathrm{B} 10$ and $652 \pm 26 \mathrm{nmol} \mathrm{min}^{-1}(\mathrm{mg} \text { protein) })^{-1}$ for RC85. 
The key enzymes of the glyoxylate cycle, isocitrate lyase (ICL) and malate synthase (MS) were assayed in extracts of acetate-grown cells of strains B10, RC85 and RC87, and in three other wild-type strains of $R$. capsulatus (JH1, LB1 and St Louis). Both enzymes were present at high levels in extracts of all the strains tested, the activities being in the range $150-360 \mathrm{nmol} \mathrm{min}^{-1}$ (mg protein) $)^{-1}$ for ICL, and $400-1130 \mathrm{nmol} \mathrm{min}^{-1}$ (mg protein) ${ }^{-1}$ for MS. In contrast, in three strains of $R$. sphaeroides (WS22 Lys ${ }^{+}, 2.4 .1 \mathrm{Ga}$ and HR), ICL activity was undetectable in extracts of acetate-grown cells, although MS activity was present at similar levels to those in $R$. capsulatus. It should be noted that the spectrophotometric assay used for ICL is not specific for the formation of glyoxylate phenylhydrazone, and non-specific activity due to isocitrate dehydrogenase has been detected in extracts of several Hyphomicrobium strains (Attwood \& Harder, 1977). Nevertheless, in contrast to Hyphomicrobium, the activities measured in $R$. capsulatus strains were significantly higher than the specific ICL activity required to support the observed growth rate on acetate, which was calculated to be $93 \mathrm{nmol} \mathrm{\textrm {min } ^ { - 1 }}$ (mg protein) $)^{-1}$.

\section{DISCUSSION}

One purpose of the present work was to identify clearly the enzymes involved in pyruvate metabolism in Rhodobacter capsulatus. The results obtained are incorporated into the scheme shown in Fig. 2, which shows the central pathways of carbon metabolism in R. capsulatus. Other enzymes are clearly also involved in pyruvate metabolism, and indeed the 'non-specific' enzyme activity observed in some of the assays described above was largely pyruvate-dependent. However, this activity, which varied between 20 and $50 \mathrm{nmol} \mathrm{min}^{-1}(\mathrm{mg} \text { protein) })^{-1}$, depending on the assay conditions, was present at similar levels in extracts of the wild-type and mutant cells, and showed little dependence on the carbon source used for growth, suggesting that the enzymes involved are not crucial for pyruvate assimilation.

PC is clearly the major enzyme involved in the generation of tricarboxylic acid cycle intermediates from pyruvate, since its absence in the mutant strains RC85 and RC87 results in a complete loss of the ability to grow on pyruvate, or on substrates metabolized via pyruvate, when these are provided as sole carbon source. A combination of PCK and PK might have been thought to allow growth on pyruvate, but PCK clearly plays a gluconeogenic role in $R$. capsulatus. This is the case in most bacteria, although an exception is Alcaligenes eutrophus, which has no PC activity, and appears to assimilate pyruvate via PPS and PCK (Schobert \& Bowien, 1984). Moreover, the low level of PK activity in lactate-grown cells of the wild-type suggests that this enzyme functions mainly to generate pyruvate. The mutants RC85 and RC87 grew on acetate after a long lag period, and this growth may have been due either to the activity of residual levels of PC or of other anaplerotic enzymes, or to the relief of a blockage in the citric acid cycle. One possible site for blockage of the citric acid cycle is isocitrate dehydrogenase, which in $E$. coli is a regulatory enzyme, controlled by covalent modification (phosphorylation/ dephosphorylation), that is influenced by a number of effectors, including pyruvate (El-Mansi $e t$ al., 1986). Revertants of the insertion mutant RC87 were obtained which were able to grow on lactate, but which still lacked PC activity. They also grew on acetate without an extended lag period. These revertants presumably contained a second-site mutation, which either increased the activity of another anaplerotic enzyme, or decreased inhibition of the citric acid cycle.

It is difficult to extrapolate from in vitro assays to the in vivo situation, since many of the enzymes involved in pyruvate metabolism are allosteric, and are modulated by numerous effectors (see e.g. Klemme, 1974). However, the differences in activity observed between cellfree extracts must at least partly reflect differences in the level of synthesis and/or irreversible (i.e. covalent) modification of activity. Indeed, many of the variations in enzyme activity observed can be rationalized by assuming that the enzyme levels respond, either directly or indirectly, to the relative intracellular concentrations of pyruvate and oxaloacetate. Thus, in the PC-deficient mutants, which might be expected to accumulate pyruvate intracellularly and to have low levels of oxaloacetate, the average level of PCK was higher than in the wild-type. Furthermore, in acetate-grown cells of the wild-type, which lack PDH activity, and also contain low levels of PC, the activity of PCK was higher than in lactate-grown or malate-grown cells. 


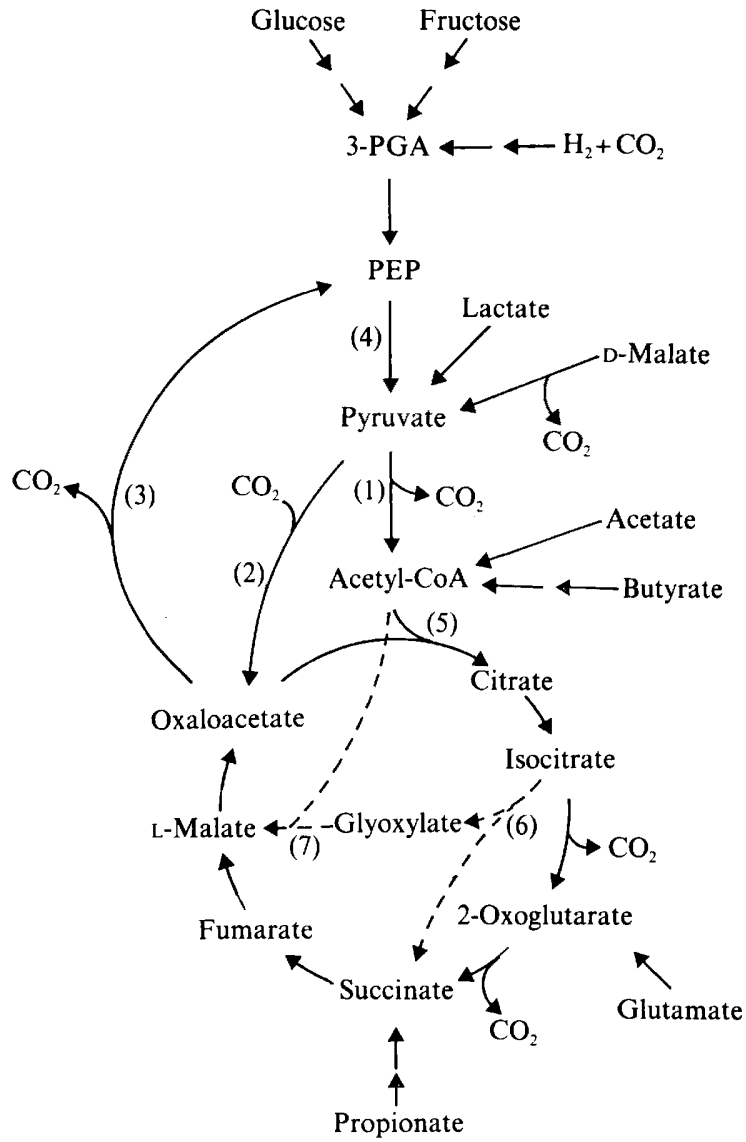

Fig. 2. Central pathways of carbon metabolism in $R$. capsulatus. See text for references, except for propionate, which has been shown by labelling studies to be metabolized via succinate (Knight, 1962) and D-malate, which is oxidatively decarboxylated by an NAD ${ }^{+}$-dependent D-malic enzyme (Willison et al., 1984). The enzymes assayed in the present study are numbered as follows: (1) pyruvate dehydrogenase (PDH); (2) pyruvate carboxylase (PC); (3) phosphoenolpyruvate carboxykinase (PCK); (4) pyruvate kinase (PK); (5) citrate synthase (CS); (6) isocitrate lyase (ICL); (7) malate synthase (MS). Mutants lacking PC are unable to grow autotrophically on $\mathrm{H}_{2}+\mathrm{CO}_{2}$, or heterotrophically on glucose, lactate, D-malate or pyruvate, but are able to grow on acetate, butyrate, glutamate, propionate, succinate and L-malate. PC is therefore the major anaplerotic enzyme responsible for growth on pyruvate, and PCK and PK probably function essentially in the directions shown.

Conversely, in malate-grown cells, in which the level of oxaloacetate would be expected to be high relative to that of pyruvate, the average level of PCK was relatively low. It should be noted that, for certain carbon sources, the activities of PC, PCK and PK varied widely between extracts, possibly reflecting variations in the intraceilular levels of metabolites.

In contrast to other enzymes, the level of PDH activity was fairly constant, and was similar in extracts of lactate-grown and malate-grown cells. However, in extracts of acetate-grown cells, PDH activity was undetectable and therefore corresponded to less than $1-2 \%$ of the activity present in other extracts. This degree of inhibition is more drastic than that observed in E. coli, where the level of PDH activity in acetate-grown cells was about $15 \%$ of that found in extracts of pyruvate-grown cells (Langley \& Guest, 1978).

Overall, the pyruvate metabolism of $R$. capsulatus closely resembles that of $R$. sphaeroides. A mutant of $R$. sphaeroides lacking PC was isolated by Payne \& Morris (1969), and showed properties very similar to those of the mutants described here. $R$. sphaeroides contains phosphoenolpyruvate carboxykinase (PCK) and lacks phosphoenolpyruvate carboxylase (Payne 
$\&$ Morris, 1969), and the properties of PK in $R$. capsulatus closely resemble those of the $R$. sphaeroides enzyme.

In contrast, $R$. capsulatus and $R$. sphaeroides differ significantly in terms of acetate metabolism. Kornberg \& Lascelles (1960) initially showed that an $R$. capsulatus strain contained ICL, while strains of $R$. sphaeroides and Rhodospirillum rubrum appeared to lack this enzyme. However, Albers \& Gottschalk (1976) later showed that ICL activity was absent in $R$. capsulatus strain $\mathrm{Kbl}$, and in the review by Kondratieva (1979), $R$. capsulatus is listed with $R$. sphaeroides and $R s p$. rubrum as being $\mathrm{ICL}^{-}$. In the present study, ICL activity was assayed in extracts of four wild-type strains of $R$. capsulatus and three strains of $R$. sphaeroides: all four $R$. capsulatus strains were $\mathrm{ICL}^{+}$, whereas all three $R$. sphaeroides strains were $\mathrm{ICL}^{-}$. The species $R$. capsulatus should therefore be considered generally $\mathrm{ICL}^{+}$, and $R$. sphaeroides generally $\mathrm{ICL}^{-}$, although individual strains may diverge from this pattern.

A similar dichotomy with regard to ICL activity has been observed in methylotrophic bacteria which use the serine pathway of $\mathrm{C}_{1}$ metabolism, some of which are $\mathrm{ICL}^{+}$and others $\mathrm{ICL}^{-}$(see Anthony, 1982), and also in Thiobacillus versutus, which is apparently $\mathrm{ICL}^{+}$during anaerobic growth on acetate and nitrate and $\mathrm{ICL}^{-}$during aerobic growth (Claassen \& Zehnder, 1986). Interestingly, the mechanism by which these $\mathrm{ICL}^{-}$bacteria grow on acetate is unknown, although an hypothetical pathway involving homocitrate synthase and homoisocitrate lyase has been proposed (see Anthony, 1982).

I should like to thank Bertrand Pain, of the Ecole Normale Supérieure Saint-Cloud, Paris, for performing some of the preliminary experiments in this work, and Jacqueline Chabert for technical assistance. I also thank Jacqueline Boyer for typing the manuscript, and Dr P. M. Vignais for support and encouragement. This work was supported by grants from the Centre National de la Recherche Scientifique (CNRS, APP PIRSEM) to Dr P. M. Vignais.

\section{REFERENCES}

Albers, H. \& GotTschalk, G. (1976). Acetate metabolism in Rhodopseudomonas gelatinosa and several other Rhodospirillaceae. Archives of Microbiology 111, 45-49.

ANTHONY, C. (1982). The Biochemistry of Methylotrophs, Ch. 4, The serine pathway of formaldehyde assimilation, pp. 95-136. London: Academic Press.

ATTWOOD, M. M. \& HARDER, W. (1977). Isocitrate lyase activity in Hyphomicrobium spp: a critical reappraisal. FEMS Microbiology Letters 1, 25-30.

Claassen, P. A. M. \& Zehnder, A. J. B. (1986). Isocitrate lyase activity in Thiobacillus versutus grown anaerobically on acetate and nitrate. Journal of General Microbiology 132, 3179-3185.

ConRad, R. \& Schlegel, H. G. (1974). Different pathways for fructose and glucose utilization in Rhodopseudomonas capsulata and demonstration of 1-phosphofructokinase in phototrophic bacteria. Biochimica et biophysica acta 358, 221-225.

Dixon, G. H. \& KornberG, H. L. (1959). Assay methods for key enzymes of the glyoxylate cycle. Biochemical Journal 72, 3P.

EIDELS, L. \& Preiss, J. (1970a). Citrate synthase: a regulatory enzyme from Rhodopseudomonas capsulata. Journal of Biological Chemistry 245, 2937-2945.

EIDELs, L. \& Preiss, J. (1970b). Carbohydrate metabolism in Rhodopseudomonas capsulata: enzyme titers, glucose metabolism and polyglucose polymer synthesis. Archives of Biochemistry and Biophysics 140, 7589.

El-Mansi, E. M. T., Nimmo, H. G. \& Holms, W. H. (1986). Pyruvate metabolism and the phosphorylation state of isocitrate dehydrogenase in Escherichia coli. Journal of General Microbiology 132, 797-806.
FULLER, R. C. (1978). Photosynthetic carbon metabolism in the green and purple bacteria. In The Photosynthetic Bacteria, pp. 691-705. Edited by R. K. Clayton \& W. R. Sistrom. New York \& London: Plenum Press.

Gibson, J. L. \& TABITA, F. R. (1977). Different molecular forms of D-ribulose-1,5-bisphosphate carboxylase from Rhodopseudomonas sphaeroides. Journal of Biological Chemistry 252, 943-949.

Guest, J. R. \& Creaghan, I. T. (1973). Gene-protein relationships of the $\alpha$-keto acid dehydrogenase complexes of Escherichia coli $\mathrm{K} 12$ : isolation and characterization of lipoamide dehydrogenase mutants. Journal of General Microbiology 75, 197210.

Hess, B. \& WIEKER, H. J. (1974). Pyruvate kinase from yeast. In Methods of Enzymatic Analysis, vol. 2, pp. 778-783. Edited by H. U. Bergmeyer. New York: Academic Press.

Hillmer, P. \& GeST, H. (1977a). $\mathrm{H}_{2}$ metabolism in the photosynthetic bacterium Rhodopseudomonas capsulata: $\mathrm{H}_{2}$ production by growing cultures. Journal of Bacteriology 129, 724-731.

Hillmer, P. \& GeST, H. (1977b). $\mathrm{H}_{2}$ metabolism in the photosynthetic bacterium Rhodopseudomonas capsulata: production and utilization of $\mathrm{H}_{2}$ by resting cells. Journal of Bacteriology 129, 732-739.

Imhoff, J. F., Truper, H. G. \& Pfennig, N. (1984). Rearrangement of the species and genera of the phototrophic 'purple nonsulfur bacteria'. International Journal of Systematic Bacteriology 34, 340-343. KLEMME, J. H. (1974). Modulation by fumerate of a $P_{i}$ insensitive pyruvate kinase from Rhodopseudomonas capsulata. Archives of Microbiology 100, 57-63. 
KNIGHT, M. (1962). The photometabolism of propionate by Rhodospirillum rubrum. Biochemical Journal 84, 170-185.

KondRATIEVA, E. N. (1979). Interrelation between modes of carbon assimilation and energy production in phototrophic purple and green bacteria. In International Review of Biochemistry, Microbial Biochemistry, vol. 21, pp. 117-175. Edited by J. R. Quayle. Baltimore: University Park Press.

Kornberg, H. L. \& LASCelles, J. (1960). The formation of isocitratase by the Athiorhodaceae. Journal of General Microbiology 23, 511-517.

LANGLEY, D. \& GUEST, J. R. (1977). Biochemical genetics of the $\alpha$-keto acid dehydrogenase complexes of Escherichia coli $\mathrm{K} 12$ : isolation and biochemical properties of deletion mutants. Journal of General Microbiology 99, 263-276.

LANGley, D. \& Guest, J. R. (1978). Biochemical genetics of the $\alpha$-keto acid dehydrogenase complexes of Escherichia coli K 12: genetic characterization and regulatory properties of deletion mutants. Journal of General Microbiology 106, 103-117.

Macler, B. A., Pelroy, R. A. \& Bassham, J. A. (1979). Hydrogen formation in nearly stoichiometric amounts from glucose by a Rhodopseudomonas sphaeroides mutant. Journal of Bacteriology 138, 446452.

MARRS, B. (1974). Genetic recombination in Rhodopseudomonas capsulata. Proceedings of the National Academy of Sciences of the United States of America 71, 971-973.

Payne, J. \& Morris, J. B. (1969). Pyruvate carboxylase in Rhodopseudomonas sphaeroides. Journal of General Microbiology 59, 97-101.

Schedel, M., Klemme, J. H. \& Schlegel, H. G. (1975). Regulation of $C_{3}$-enzymes in facultative phototrophic bacteria: the cold-labile pyruvate kinase of Rhodopseudomonas sphaeroides. Archives of Microbiology 103, 237-245.
SCHOBERT, P. \& BowIEN, B. (1984). Unusual $C_{3}$ and $C_{4}$ metabolism in the chemoautotroph Alcaligenes eutrophus. Journal of Bacteriology 159, 167-172.

SISTROM, W. R. (1977). Transfer of chromosomal genes mediated by plasmid R68:45 in Rhodopseudomonas sphaeroides. Journal of Bacteriology 131, 526-532.

Stoppani, A. O. M., Fuller, R. C. \& Calvin, M. (1955). Carbon dioxide fixation by Rhodopseudomonas capsulatus. Journal of Bacteriology 69, 491501.

Vignais, P. M., Colbeau, A., Willison, J. C. \& JouANNEAU, Y. (1985). Hydrogenase, nitrogenase and hydrogen metabolism in the photosynthetic bacteria. Advances in Microbial Physiology 26, 155234.

WEAVER, K. E. \& TABITA, F. R. (1983). Isolation and partial characterization of Rhodopseudomonas sphaeroides mutants defective in the regulation of ribulose bisphosphate carboxylase/oxygenase. Journal of Bacteriology 156, 507-515.

Weaver, P. F., Wall, J. D. \& Gest, H. (1975). Characterization of Rhodopseudomonas capsulata. Archives of Microbiology 105, 207-216.

Willison, J. C., MADERN, D. \& Vignais, P. M. (1984). Increased photoproduction of hydrogen by nonautotrophic mutants of Rhodopseudomonas capsulata. Biochemical Journal 219, 593-600.

Willison, J. C., Ahombo, G., Chabert, J., Magnin, J. P. \& Vignais, P. M. (1985). Genetic mapping of the Rhodopseudomonas capsulata chromosome shows non-clustering of genes involved in nitrogen fixation. Journal of General Microbiology 131, 3001-3015.

Willison, J. C., Magnin, J. P. \& Vignais, P. M. (1987). Isolation and characterization of Rhodobacter capsulatus strains lacking endogenous plasmids. Archives of Microbiology 147, 134-142. 